\title{
Socialism and Identity in the Life and Works of Richard Wright
}

Fecha de recepción: 18 de junio de 2014

Fecha de aprobación: 21 de noviembre de 2014

\section{Abstract}

Richard Wright was a pioneer in American Literature whose relationship with socialism helped to define him as a person and as a writer. The inspiration behind his literary accomplishments and their impact on his contemporaries can be understood by tracing two of the most important themes in his life; socialism and identity. This article describes the evolution of his relationship with socialism in order to better understand the writer and his best known works in their social and political context. This exercise can also help us to gain a clearer understanding of the cultural and social implications of socialist ideology in the United States after the First World War.

Key words: Richard Wright, communism, racism, politics, socialism

* Artículo de reflexión auspiciado por el Instituto de Filosofía de la Universidad de Antioquia y hace parte de la producción del Grupo de Filosofía y Literatura.

Citar: Gómez, J.D. (julio-diciembre de 2015). Socialism and identity in the life and works of Richard Wright. La palabra, (27), 33 - 43.
Juan D. Gómez

Universidad de Antioquia

jdgomez7@gmail.com

Docente Instituto de Filosofía, Universidad de Antioquia. Miembro del Grupo de Filosofía y Literatura. Miembro de la Modern Language Association. 


\section{Socialismo e identidad en la vida y obra de Richard Wright}

\section{Resumen}

Richard Wright fue un pionero en la literatura americana cuya relación con el socialismo ayudo a definirlo como persona y como escritor. La inspiración detrás de sus logros literarios y su impacto en sus contemporáneos pueden ser entendidos mediante el trazado de dos de los temas más importantes de su vida; el socialismo y la identidad. En este artículo se describe la evolución de su relación con el socialismo, a fin de comprender mejor al escritor y sus obras más conocidas en su contexto social y político. Este ejercicio también puede ayudar a obtener una comprensión más clara de las implicaciones culturales y sociales de la ideología socialista en los Estados Unidos después de la Primera Guerra Mundial.

Palabras Claves: Richard Wright, comunismo, racismo, política, socialismo

\section{Socialisme et identité dans la vie et l'œuvre de Richard Wright}

\section{Résumé:}

Richard Wright fut un pionnier de la littérature américaine. Son rapport avec le socialisme a été essentiel dans son parcours personnel et littéraire. L'inspiration, source de ses réussites littéraires et l'impact qu'il a eu sur ses contemporains, peuvent être compris à la lumière de deux thèmes ayant été importants pour lui : le socialisme et l'identité. L'article met en perspective l'évolution de son rapport au socialisme pour mieux cerner l'écrivain et ses œuvres majeures inscrites dans un contexte socio-politique précis. Cet exercice permet de mieux comprendre les influences socio-culturelles du socialisme aux États-Unis après la Première Guerre Mondiale.

Mots clés: Richard Wright, communisme, racisme, politique, socialisme 
The life and works of Richard Wright provide a unique view of the important role that socialist ideology played in the life of many African Americans before the Second World War. Through his short stories, novels, and poems, which are in many ways an extension of the author's struggles and evolving beliefs, Wright works through many of the hopes and challenges that came with seeing socialist ideology as a possible ally in the quest for racial equality in the United States.

\section{The search for identity}

In a nation devoted to the proposition of promoting and recognizing autonomous individuals, Richard Wright's family could trace their pursuit of this ideal back to the American Civil War. When a Union soldier named Richard Wilson went through the discharge process at the end of the Civil War, his name was entered into the veteran's registry as Richard Vincent. Wilson, who was Richard Wright's maternal grandfather, spent the rest of his life trying to convince the government that he had fought in the war and, more importantly, that he existed and deserved the same government pension to which other veterans were entitled. Throughout his life and in his works of fiction Wright was involved in a similar struggle- that of making his identity known and of incorporating himself into the larger whole.

He had unpropitious beginnings, and seemed destined to a life of anonymity similar to that of Richard Vincent. Wright was born on September 4, 1908, on Rucker's plantation, some twenty miles outside of Natchez, Mississippi. When he was five, his family moved to Memphis and his father abandoned them. When Richard was eleven, his mother suffered a paralyzing stroke and the family was broken up. Wright moved in with his illiterate and devout grandmother who interpreted his restless mind and independent spirit as signs of spiritual perdition and saw it as her duty to return him to the fold. She set about doing this by restricting his access to books and the outside world (Rowley, 2001, p. 10).

At the age of 19 , in search of opportunities that would allow him to define himself, he moved to Chicago. He was surprised by the absence of Jim Crow restrictions there and heartened by the possibility of living his life without the fear of lynching. It was in there where he had his first contact with communists. $\mathrm{He}$ saw their marches, and sometimes he witnessed black men among them, parading and mimicking the mannerisms of white communists. Wright was unimpressed and concluded that these black men were dupes who naively thought of themselves as practicing a kind of magic and hoped that if "... they acted like the men who overthrew the Czar, then surely they ought to win their freedom in America" (Wright, 1983, pp. 37-38).

Like many others in Chicago during the Depression, Wright survived through a combination of sporadic employment and public assistance. For a time, he worked in a post office where he befriended white men who introduced him to the John Reed Club, a national communist organization that sought to recruit writers and intellectuals. Wright was skeptical about white/communist interest in black welfare but he was won over and eventually became one of the converted. He quickly rose through the ranks from recruit to executive secretary of the Chicago chapter and, for the first time in his life, found himself surrounded by like-minded individuals that valued him for his ideas and imagination.

The club provided an ideology that opposed his grandmother's benighted mysticism and a movement that engaged in an organized search for the truth in the lives of the oppressed and isolated (Gayle, 1980, p. 68). Here, at last, he had found what he needed: an identity beyond the procrustean norms 
that white society imposed and a means to challenge them. Six years later, when the Soviet-Nazi pact caused many to abandon the party, Wright remained. $\mathrm{He}$ explained his position by saying, "Communism is for me a way of life, a spectacle of life, an unusual mode of existence, an intense drama ... millions, regardless of the tactics of the U.S.S.R stand firm, for there is nothing to go back to" (Gayle, 1980, p. 123; emphasis added).

It was during his John Reed membership that Wright's long harbored feelings of indignation, frustration, and hope for a better future founded on reason and justice were transformed into social activism, artistic production, and socialist militancy. Socialism gave him a collective identity. It allowed his isolated suffering to be projected onto a global stage where his individual tale became one with that of millions of others; their plight became part of his life and he became part of their struggle. He wrote, "I was a communist because I was a Negro. Indeed the Communist Party had been the only road out of the black belt for me. Hence communism had not been for me simply a fad, a hobby; it had a deep functional meaning for my life" (Fabre, 1993, p. 23). Socialist ideology was for him a belief system as personal as any religion. Like the Christianity practiced by his enslaved ancestors, its form of practice changed but he never abandoned the ideal because the cause was essential to who he was. This remained true even when those who introduced him to it, and those who claimed sole representation of it, would turn oppressive and tyrannical.

The works that Wright published during this time, poems like "A Red Love Note", and "I Have Seen Black Hands" voice his hope that the Party would provide the organizational structure that could bring blacks together and thrust them into an active role in the political, economic, and social life of the country. At the same time, poems like "Between the World and Me", a disturbingly vivid description of a lynching, remind the reader of the barbaric violence that whites were allowed to inflict on blacks with impunity in parts of the country.

\section{The acclaimed writer}

In 1936, his short story, "Big Boy Leaves Home", was included in The New Caravan Anthology. This story, along with "Fire and Cloud", which won the National Fiction Contest in 1937, and others were published together as Uncle Tom's Children (UTC) in 1938. In this collection, we find Wright's first complete artistic engagement with the possibilities and tensions that existed between race, socialism, religion, and collective identity. He hoped to exploit these possibilities and resolve the tensions that emerged from them lest they undermine black unity and his own fragile and developing sense of self1.

The possibilities and risks can be seen in all of the stories in UTC whose protagonists engage in varying degrees of rebellion and collective resistance. This resistance is sometimes organized around the black church and, to a lesser extent, the Communist Party. The first three stories carry a warning to the enemy (read, capitalists and racists) by highlighting some of the violent possibilities inherent in all abusive relationships and warn blacks about the ineffectiveness of pursuing individual actions. The implication being that only a communal movement, based on an established (blackcommunist) group identity has a chance of succeeding.

The protagonists in these stories, two men and an adolescent are forced to choose between submission and selfassertion. All three choose the latter for different reasons and

1 For more on the tensions inherent in the interactions between race, socialism, and religion see Hakutani, 1996. 
with different consequences, but an undertone of rebellion and attempts at self-definition are common to all three. The stories announce an end to black submissiveness and forecast that it is likely to be a violent one.

Big Boy, the title character in "Big Boy Leaves Home", shoots a white man who has killed one of his friends; Brother Mann in "Down by the Riverside" kills a white postmaster in selfdefense; and Silas, in "Long Black Song", whips a white salesman who has seduced his pregnant wife. When the white salesman's friend comes to help, Silas shoots him. When the authorities arrive, he hunkers down in his house, shoots back, and burns it to the ground. Silas is exceptional in that he is a black property owner and is thus under the impression that he has an identity of sorts within the capitalist system. Despite this, he suffers the same fate as the non-owners in UTC. His wife is also presented as an extension of his property, property that is unlawfully taken from him. The message here is that only a collective socialist-racial identity can have some staying power and that believing in an individual sense of self in a capitalist society is, at best, delusional.

The last two stories in UTC try to hasten the working classes to revolutionary action by presenting a class uprising as imminent. "Fire and Cloud" and "Bright and Morning Star", which were added to the 1940 edition, assume that class can be a greater historical determinant than race. In "Fire and Cloud" Wright focuses on the Church- the most important communal structure in southern black society. The Reverend Dan Taylor, torn between his responsibility to his congregation and fear for his life, vacillates between joining the communists in a march to demand food from the local government and yielding to the threats made by the town's officials. After being kidnapped and whipped, Taylor allows that Marxism and Christianity may in fact be compatible for political purposes.

In the end, a crowd of poor blacks and whites march together and have their demands met by the mayor. The march shows how through religion and socialism a new collective identity can be achieved and how the racial identities that predominate can be supplanted to the benefit of all. This joining of the Christian vision and the new Marxism is meant to bring class-consciousness to Reverend Taylor's congregation. By uniting the cultural strength of the citizens with the guided political action of the communists, Christianity becomes not a foe to Marxism but a tactical ally that can help to define revolutionary consciousness. Through these stories, Wright tries to harmonize the source of black unity- spiritual belief and socialist ideology, because he sees them as necessary catalysts for a new society to emerge and also for a reconciliation between his own past and present.

The heroine in "Bright and Morning Star" is a generation ahead of Reverend Taylor in political enlightenment. Her faith in the communist cause is as strong as her faith in Christ and this, instead of dividing her spiritual strength, has the effect of doubling her capacity for courageous action. There is no time for gradual assimilation in this story and self-sacrifice is understood to be the price of solidarity and ultimate victory. The heroine has one son imprisoned for being a communist and she is willing to watch the sheriff and his mob torture a second son in order to protect the identities of comrades in her cell. Although the story ends with the death of our heroine and her son, there is an understood sense of accomplishment because the group is now stronger. It is composed of individuals who place its survival above their own, who have come to a communal identity through suffering and are autonomous individuals defined by their own principles and actions 
rather than by those who seek to exploit them.

These stories show a transition stage for Wright. He is no longer in the honeymoon stage of the earlier poems, such as "A Red Love Note" for example, but is trying to pave, through fiction, a path that will lead African Americans out of poverty, oppression, violence, and into a new sense of self. The path, he hopes, will be paved with socialist stones. Wright knew that the obstacles to achieving class unity were many and he devotes a substantial portion of his most famous novel, Native Son, to addressing them.

\section{The communist and the} native son

Before he could write Native Son however, the uncompromising character and integrity that saw him through violence, hunger, and isolation, became the cause of many of his problems with his communist brethren. The Party demanded conformity and the relationship could not last. Although his formal education was not much more than that of the rank and file with whom he sought to work, his shined shoes, clean shirt, and tie got him labeled an intellectual. He began receiving threats on his life; he was feared because he was not familiar. Wright summarized his situation thus: "God I love these people but I'm glad they're not in power, or they'd shoot me" (Wright, 1983, p. 119). He seemed to be back in the place from where he had hoped to escape. In Memphis, or in his grandmother's house, where he was forced to be who others thought he should be, where his sense of self had to bend to the will of those more powerful.

Wright's disagreement with the Party was not his only concern. As part of the Federal Writers' Project (FWP), an effort to discover American culture through the voices of ex-slaves, factory hands, and farm workers, Wright tried to bring the lives of black Americans to the public's attention by writing their history and articulating their collective identity. As anti-communist sentiment spread, the project drew the attention of Texas congressman Martin Dies. Dies chaired what was to become the House Un-American Activities Committee (HUAC) and saw the FWP's activities as a communist plot to subvert American national identity; consequently the project was terminated on the federal level in 1939. The government was not interested in black Americans discovering who they were and they were not interested in the rest of the country knowing about their lives.

Wright himself later became the object of government persecution because of his affiliation with the Communist Party and his unyielding and sometimes militant denunciations of racism in America. In 1940 he had his passport confiscated by authorities who tried blackmailing him into signing a declaration attesting to a communist conspiracy (Gayle, 1980 , p. xiv). It was soon clear to him that a new kind of chauvinism was taking over in the United States, one in which American was synonymous with capitalist, communist meant un-American, and black communists were doubly so because they had never been considered American to begin with. Searching for a way to engage with the political machine that refused to recognize them as citizens, Wright and others were labeled as traitors instead. ${ }^{2}$

The red and the black forces that reactionary government officials judged to be the principal threats to the status quo were conflated so that petitions for civil rights were labeled seditious. Despite this, Richard Wright remained

2 Gayle makes the case that the U.S. government, through the CIA and the FBI, continued to harass Wright overseas for his non-conformity and advocacy for the oppressed as they had done in the United States. 
a speaker in the tradition of the oppressed and continued, at great cost to himself and his family, to confront power with truth.

Wright left Chicago for New York and took with him the ideology that had become a complement to his identity as a black man and as a writer. His interest now lay in distilling from the Garveyist and Black Nationalist movements a program for black unity that was guided by the principles and ideals of socialism. It was with these concerns in mind that he set himself to write Native Son.

Native Son depicts a time and place in which the possibility of a significant socialist presence in American politics was real. The moment was brief but its consequences helped to define the future of the movement for racial equality in the U.S. In it, Wright presents the racial divide in the U.S. as a conflict with consequences of national magnitude. The future of the country, Wright contends, would be defined in large part by its ability to acknowledge its biracial identity. In "How Bigger Was Born”, a lecture given by Wright at Columbia University in March of 1940 , he explains the birth of Native Son's protagonist through a geopolitical prism that includes the conflict in Europe and many of the questions that Fascism raised. He tells us that Bigger, as a dispossessed and disinherited man without any positive sense of self, “... carried in him the potentialities of either communism or fascism." and that he (Wright) came to understand the moods and impulses of blacks in Chicago by learning about Russian life under the Czars (Wright, 1993, p. 521, 518). And although Bigger Thomas is not exactly a revolutionary, even Wright tells us that he recognized in his character impulses that "... were present in the vast upheavals in Russia and Germany" (Wright, 1993 , p. 529). He is tragic, and Wright's lecture is instructive because in it we see that for him the black struggle and his socialist ideals were inseparable parts of the self that he saw himself to be.

The initial response to the novel was unmistakably favorable. It was chosen as a Book of the Month Club selection and sold exceedingly well; Lewis Gannet's review in The New York Herald Tribune likened it to Steinbeck's Grapes of Wrath and Charles Poore of The New York Times declared that it had been a long time since he encountered “... a novelist who had such command of the techniques and resources of the novel" (Reilly, 1978, p. 43). Some critics failed to appreciate the importance of what the novel exposed; Clifton Fadiman of The New Yorker wrote that Wright was less than a finished novelist and that his melodramatic plot was peopled with paper-thin characters (Reilly, 1978, p. 47). What no one could deny however was that Wright had acquired a new and paradoxical identity: he had become the first black bestselling author. ${ }^{3}$

In Native Son it is the denial of identity and alienation that young black men (to say nothing of the women who are almost always worse off) face that precipitates tragedy. Wright saw this sense of exclusion as a threat to them and to anyone else who chanced to be near. Bigger Thomas, like the author, is seldom perceived as a whole person. Throughout the novel he is quartered and objectified by the whites in power and responds by alternating between periods of dejected impotence and rage. Wright explains Bigger's alienation through the prism of dialectical materialism so that the novel's social protest is founded on the socialist theoretical constructs with which Wright was familiar. Within this paradigm, white people, who represent the oppositional force that Bigger

3 In 1939, Wright declared earnings of $\$ 2,585$, and in 1940 , close to $\$ 30,000$ (Fabre 249).

4 The socialist theme is at times over represented when Wright displaces the racial agenda by forcing abstract theoretical observations onto the story of Bigger Thomas. 
perceives as the most dangerous to him, manifest their power over him through material forms. ${ }^{4}$

Bigger is very much like any other young black man living in Chicago's Southside except for that a charitable organization run by Mr. Dalton, the wealthiest real estate man in Chicago, has chosen to award him with a life altering opportunity, to become a driver for the Dalton family. At the intersection of these two worlds lies the heart of the novel. Bigger accidentally kills Mr. Dalton's daughter, disposes of her body in the basement furnace, and a short manhunt ensues; these events take place in the "Fear" and "Flight" sections of the novel. In the "Fate" section, Bigger murders his girlfriend, is captured, and brought to court to face the death penalty. He is defended by a communist lawyer and loses.

The plot of Native Son is directed at exposing the economic factors that underlie the subhuman conditions in which black Chicagoans in the 1930's were forced to live. The few black characters that Bigger comes into contact with are constant reminders of the economic power of whites. His mother, sister, and brother survive on public assistance. His sister Vera takes sewing classes and hopes for the day when she will be old enough to work. Bigger's girlfriend Bessie earns just enough as a cleaning woman to sustain herself, and arrives home numbed by exhaustion. These characters live on the fringes of the capitalist system and are therefore denied the privilege of a social identity in the world of whites; they are unable to have lives of their own because their days are taken up by the unending struggle for survival. Without a job, Bigger's only sense of community comes from his accomplices; with them he robs black merchants in the neighborhood so that he can have money for cigarettes and booze. The racial oppression in Native Son is codified into a system of social relations of power that are defined by the distribution of wealth. For individual characters, selfrealization is a commodity to which they are denied access because they are poor.

The representation of the Communist Party in the novel echoes Wright's personal evolution in that it is ambiguous and measured. Wright gives the Party a role to play through Jan Erlone, the concerned and committed communist, and Boris Max, the earnest but ineffective comrade. This lack of consistency in representing the Party illustrates the ideological shift that Wright faced in his move away from it and toward socialist ideals. His relationship with the Party was unhealthy and, although he was strong enough to end it, the process proved to be lengthy and painful.

The communists in the novel are misunderstood and misunderstand. They are moved by egalitarian principles but their strategy for realizing them is most often ineffective and sometimes counterproductive (Galllagher, 2009, p. 5). Wright sympathizes with their position and places them on the right side of the argument, but his reservations about politics and communism in particular are deep-set. He had, by this point in his life, had enough experience with the inhibiting qualities of Party bureaucracy and the impractical effects of its dogmatism to know its limitations. Still, the central role played by the communists in Native Son would lead us to conclude that for Wright, the Party was certainly better than anything available in the past and, for some, the best of what the present had to offer.

When Irving Howe said of $\mathrm{Na}$ tive Son that it was a novel that "... made impossible a repetition of the old lies ...", (Howe, 1963 , p. 354) he was referring to race relations in the U.S. But he could just as well have meant that in this novel, and those that followed, it was impossible for Wright to repeat the old lies 
about communism because the circumstances demanded that he address the issue of race and class relations from a new vantage point. Class unity provided Wright with this, with a new paradigm with which to address the racial problem and with a means to indict the failure of the U.S. to live up to its ideals.

\section{The search for a new iden-} tity

In the works that Wright published after Native Son he attempted to develop this new paradigm, one that tries to bridge the racial past with a socialist future (Kinnamon, 1990, p. 3).5 One example of this came in 1941 when Wright and the photographer Edwin Roskam published Twelve Million Black Voices: A Folk Story of the Negro in the U.S. In it, Wright defines white power in the U.S. in economic terms by talking about "The Lords of the Lands" and "The Bosses of the Buildings" (Wright, 2008, p. 49). He depicts the Jim Crow south as a place where racial oppression is but an appendage of a vaster and, in many respects, more ruthless and impersonal commodity-profit machine (Wright, 1993, p. 515). His disassociation from the Party did not mean that he was also renouncing Marxism or moving closer to American capitalism. He continued to write against white supremacy and imperialism both at home and abroad. In essays like "I Bite the Hand That Feeds Me", "Blueprint for Negro Writing", and "White Man Listen" he adapts literary techniques in order to produce works of social and political protest.

In 1941 he married a communist organizer from Brooklyn named Ellen Poplar even as his relationship with the Party deteriorated to an irreparable state and it authorized actions against him. ${ }^{6}$ Also in that year, Wright became the subject of an investigation by J. Edgar Hoover who received instructions to this effect by Secretary of War Henry Stimson upon the latter's review of Twelve Million Black Voices. Wright was again a man against forces that saw his beliefs as threatening. We see this theme of one against an intolerant society in his next published work, the short story titled: "The Man Who Lived Underground" (1942). Its protagonist, Fred Daniels, is a man in rebellion against a society of money exchange and consumption. Like Bigger (and Wright), he is a black man who is the object of a police manhunt because he is considered a threat to the community. The story is an extension of Wright's socialist position and includes themes of isolation and the search for a stable identity that Wright would give a more complete presentation to in the novel that marks the beginning of his existentialist phase, The Outsider (1953).

The protagonist in The Outsider is Cross Damon, a character free of conventional morality, inhibitions, and the collective norms of conscience. He tries to create an identity for himself by rebelling against those around him. He despises communists and fascists who he concludes to be equally ruthless, cynical, and far from revolutionary. $\mathrm{He}$ attempts to create a sovereign identity for himself by opposing the collective discipline around him, but as he lies on his deathbed at the end of the novel he realizes that "Alone, man is nothing" (p. 585). The theme of individual effort as futile is present in Wright's earliest works, as is that of the individual against the collective, both of which Wright experienced throughout his own life. Twenty years after joining the John Reed Club, Wright was back where he started. He had explored the limits of absolute freedom through existentialism and confirmed what he had suspected when he joined the

5 This task was complicated because it was Wright's emotional and subjective inclination to see history in terms of race and not class (Brignano, 1973, p. 93).

6 He would leave the Party in 1942 after a personal altercation with Benjamin Davis. 
Party: that individual action is futile and that in isolation, there is little hope for a healthy self, and life is painful to bear. In The Outsider he returned to those themes that first brought him to the Party: the need for emotional attachment, compassion, and solidarity. Through existentialism, Wright learned how individuals could resist the restrictions that the world imposed upon them. This influence can be seen in the development of Bigger, who as the novel progresses, is transformed from a naturalistic victim to an existential hero. Subsequently, Cross Damon may be read as a variation on protagonists who, like Wright, pay a heavy price for their emancipation.

Wright continued to ride Native Son's wave of popularity throughout the first half of the forties. He lectured, went on book tours, and published short stories. In 1945 his autobiographical Black Boy also appeared as a Book of the Month Selection and received general applause from the press. This book also received praise from respected novelists such as William Faulkner, who wrote to Wright, "It needed to be said and you said it well." Henry Miller wrote, "I wanted to let you know how deeply it impressed me" (as cited in Gayle, 1980, p. 178). Its representation of Jim Crow life angered many in the South and the book was banned in several southern cities. Its portrayal of the Communist Party as authoritarian upset the organization and led to more attacks on Wright.

The end of the war brought increased government scrutiny of communists. This and the Party's attacks on him created an atmosphere in which Wright was glad to accept an invitation by the French government. Wright would later be quoted as saying, "Had I not left my native land ... I would have perished in the atmosphere of political hysteria of McCarthyism" (Gayle, 1980, p. 195). ${ }^{7}$ Having lived his life in a country that had kept him an outsider from its culture and institutions, Wright was forced to impose exile status on himself. His declining popularity did not, however, diminish his active involvement in social and political causes that had helped to define him and that earned him the attention of government agencies. After moving to Paris, Wright's professional success was consistently undermined by the U.S. government. ${ }^{8}$ The State Department, CIA, and FBI saw Wright's political philosophy as dangerous and his public appeal as spokesman for colonized peoples a tool that the Soviet Union and China (particularly during the Korean War) were using to score points against the U.S. When Wright died in a Paris hospital in 1960 , his reputation was a shade of what it had been during the early 1940 s.

Wright's life, like that of many of his protagonists was tragic, but unlike theirs, it was not for naught. Through sheer obstinacy and conviction he created a life and identity for himself; he made himself felt and because of this he left his mark. His experiences as a child of the Depression and as a black man in a hostile and racist society resulted in his wholehearted embrace of the Party and, afterwards, of socialism. His literary works are a testament to the evolution of his political beliefs and illustrate some of the cultural effects of socialist ideology. The degree of faith that Wright had in the collectivist and proletariat ideal provides a glimpse of the potential that socialism had to influence disenfranchised Americans and of the wider social repercussions that could have taken place in the U.S. had socialism taken root.

\footnotetext{
7 James Baldwin and Chester Himes, also eager to flee the growing storm being fanned by the HUAC would follow, in 1948 in 1953 respectively.

8 In March of 1954, Native Son was removed from the public library in Galion, Ohio, in accordance with the anti-communist oath taken by all public educators. The Federal Loyalty Program to root out communism and those engaged in conduct "... likely to be contrary to the interests of the U.S." was initiated by President Truman's Executive Order 9835 (Gayle, 1980, p. 253).
} 


\section{References}

Brignano, R.C. (1973). Richard Wright: An Introduction to the Man and His Works. Pittsburgh, PA: University of Pittsburgh Press.

Fabre, M. (1993). The Unfinished Quest of Richard Wright. Urbana-Champaign, IL: University of Illinois Press.

Gallagher, K. (2009). Bigger's Great Leap to the Figurative. In H. Bloom (Ed.), Bloom's Modern Critical Interpretations: Richard Wright's Native Son. (pp. 3-18). New York, NY: Infobase Publishing.

Gayle, A. (1980). Richard Wright an Ordeal of a Native Son. New York, NY: Anchor Publishing.

Hakutani, Y. (1996). Richard Wright and Racial Discourse. Missouri: University of Missouri Press.

Howe, I. (1963, Autumn). Black Boys and Native Sons. Dissent, 353-368.

Kinnamon, K. (Ed.). (1990). New Essays on Native Son. New York, NY: Cambridge University Press.

Reilly, J. (Ed.). (1978). Richard Wright: The Critical Reception. New York, NY: Burt Franklyn and Company.

Rowley, H. (2001). Richard Wright: The Life and Times. Chicago, IL: Chicago University Press.

Wright, R. (1934, January). A Red Love Note. Left Front: 3.

Wright, R. (1934, June). I Have Seen Black Hands. New Masses: 16.

Wright, R. (1935, July). Between the World and Me. Partisan Review: 18-19.

Wright, R. (1937). White Man Listen. Garden City, NY: Doubleday Press.

Wright, R. (1940, June). I Bite the Hand that Feeds Me. Atlantic Monthly: 826-828.

Wright, R. (1957). Pagan Spain. London, UK: The Bodley Head Press.

Wright, R. (1961). Twelve Million Black Voices. New York, NY: Arno Press.

Wright, R. (1983). American Hunger. New York, NY: Harper Press.

Wright, R. (1989). Black Boy. New York, NY: Harper Perennial Press.

Wright, R. (1993). Native Son: and How Bigger was Born. New York, NY: Harper Perennial Press.

Wright, R. (1993). Uncle Tom's Children. New York, NY: Harper Perennial.

Wright, R. (1996). Eight Men: Stories by Richard Wright. New York, NY: Harper Perennial.

Wright, R. (1937, Fall). Blueprint for Negro Writing. New Challenge, 2, 53-65.

Wright, R. (2003). The Outsider. New York: Harper Perennial Press. 